\title{
RESPON PERTUMBUHAN DAN HASIL TANAMAN MELON (Cucumis melo L.) MELALUI PEMBERIAN POC KOTORAN SAPI DAN MULSA PLASTIK
}

\author{
Growth Response and Results Of Melon Plants (Cucumis melo L.) Through \\ The Provision Of Liquid Organic Fertilizers Cow Manure \\ and Plastic Mulch
}

\author{
Baso Amir ${ }^{1)}$, Andika Abdillah ${ }^{2)}$ \\ Email:bas_amt@yahoo.com ${ }^{1}$
}

Program Studi Agroteknologi,Fakultas Pertanian, Universitas Cokroaminoto Palopo ${ }^{12)}$

\begin{abstract}
Abstrak
Penelitian ini bertujuan untuk mengetahui respon pertumbuhan dan hasil tanaman melon dengan pemberian POC kotoran sapi dan mulsa plastik.Penelitian ini menggunakan metode Rancangan Acak Kelompok (RAK) dengan 6 perlakuan dan setiap perlakuan diulang sebanyak 4 kali, sehingga terdapat 24 unit percobaan. Adapun perlakuan yang diberikan sebagai berikut: P0 : tanpa mulsa dan poc kotoran sapi (kontrol), P1 : mulsa dan POC kotoran sapi dengan konsentrasi $50 \mathrm{ml} /$ tanaman, P2 : mulsa dan POC kotoran sapi dengan konsentrasi 100 $\mathrm{ml} /$ tanaman, P3 : mulsa dan POC kotoran sapi dengan konsentrasi $150 \mathrm{ml} /$ tanaman, P4 : mulsa dan POC kotoran sapi dengan konsentrasi $200 \mathrm{ml} /$ tanaman, P5 : Pemberian mulsa dan POC kotoran sapi dengan konsentrasi 250 $\mathrm{ml} /$ tanaman. Hasil penelitian menunjukkan bahwa pemanfaatan mulsa plastik dan POC kotoran sapi berpengaruh nyata pada tinggi tanaman, jumlah daun, jumlah buah, bobot buah, dan diameter buah.Hal ini diduga disebabkan oleh penggunaan mulsa plastik dan nutrisi pada POC kotoran sapi mampu meningkatkan pertumbuhan dan hasil tanaman melon.Pemanfaatan mulsa plastik dan POC kotoran sapi yang memberikan hasil terbaik pada perlakuan P5 (pemberian mulsa dan POC kotoran sapi dengan konsentrasi $250 \mathrm{ml} / \mathrm{tanaman}$ ) untuk jumlah buah 1.12 buah dan bobot buah $1.02 \mathrm{~kg}$
\end{abstract}

Kata kunci :Melon, Mulsa, POC, Kotoran Sapi.

\begin{abstract}
This study aims to determine the response of growth and yield of melon plants by giving of liquid organic fertilizers cow manure and plastic mulch. This study used a Randomized Block Design (RBD) method with 6 treatments and each treatment was repeated 4 times, so that there were 24 experimental units. As for the treatment given as follows: P0: without mulch and poc cow manure(control), P1: mulch and POC cow manure with a concentration of $50 \mathrm{ml} /$ plant, P2: mulch and POC cow manure with a concentration of $100 \mathrm{ml} / \mathrm{plant}$, P3: mulch and POC cow manure with a concentration of $150 \mathrm{ml} /$ plant, P4: mulch and POC cow dung with a concentration of $200 \mathrm{ml} /$ plant, P5: mulch and POC cow manure with a concentration of $250 \mathrm{ml} / \mathrm{plant}$. The results showed that the use of plastic mulch and POC of cow manure significantly affected plant height, number of leaves, number of fruits, weight of fruit, and diameter of fruit. This is thought to be caused by the use of plastic mulch and nutrients in POC cow manure can increase the growth and yield of melon plants. Utilization of plastic mulch and POC cow dung which gives the best results in the treatment of P5 (administration of mulch and POC cow dung with a concentration of $250 \mathrm{ml} /$ plant) for the number of fruits 1.12 fruit and fruit weight $1.02 \mathrm{~kg}$
\end{abstract}

Keywords :Melon, Mulch, POC, Cow Manure.

\section{PENDAHULUAN}

Tanaman melon (Cucumis melo L.)

merupakan salah satu komoditas

hortikultura yang perlu mendapat

perhatian, selain harga jualnya relatif baik dan rasa yang banyak diminati konsumen secaraumum sehingga prospek pasar untuk komoditas ini cukup baik sehingga pengembangannya layak untuk 
diperhatikan. Kebutuhan melon dalam negeri setiap tahunnya cenderung terus meningkat, sejalan dengan pertumbuhan penduduk. Menurut Badan Pusat Statistik (2017) produksi melon pada tahun 2013, 2014 dan 2015 berturut-turut 125.207; 150.365 dan 137.887 ton dan hanya memenuhi kebutuhan nasional sekitar $40 \%$, selebihnya kebutuhan dipenuhi melalui impor.

Meningkatnya kebutuhan terhadap komoditas melon menyebabkan perlunya peningkatan produksi baik secara kualitas maupun kuantitas. Permintaan masyarakat yang tinggi, menjadikan melon sebagai salah satu komoditas hortikultura unggulan (Prajnanta, 2004).Salah satu upaya untuk meninirgkatkan hasil tanaman melon adalah dengan pemilihan bibit unggul dan pemupukan yang tepat. Pemupukan adalah suatu tindakan memberikan tambahan unsur hara pada tanah baik langsung maupun tak langsung sehingga dapat menyediakan nutrisi bagi tanaman. Pemupukan merupakan hal penting yang diberikan ke tanaman agar tanaman dapat tumbuh dan berkembang dengan baik. Pertumbuhan dan perkembangan tanaman sangat dipengaruhi oleh pemberian pupuk dan ketersediaan unsur hara di dalam tanah (Irfan, 2013).

Penambahan bahan organik yang berasal dari sisa tanaman dan kotoran hewan seperti sapi selain dapat menambah bahan organik tanah juga memberikan kontribusi terhadap ketersediaan hara N, P dan $\mathrm{K}$, serta mengefesienkan penggunaan pupuk anorganik. Bahan organik dari jenis kotoran hewan (pupuk kandang sapi) umumnya mudah terurai karena $\mathrm{C} / \mathrm{N}$ rasio yang rendah. Selain itu, penggunaan bahan organik (pupuk kandang sapi) secara ekonomis murah, mudah diperoleh dan tanpa pendekatan teknologi yang tinggi sehingga relatif mudah dijangkau oleh petani. Hasil penelitian Muku (2002) menyatakan bahwa pemberian pupuk kandang sapi 15 ton per hektar menghasilkan umbi bawang merah sebanyak 15,3 ton per hektar dalam penelitian Mayun (2007) menyatakan bahwa pemberian beberapa pupuk kandang sapi dengan 30 ton per hektar memberikan pengaruh yang nyata pada pertumbuhan dan produksi sawi per hektar.

Selain penambahan bahan organik perlu juga dilakukan pemberian mulsa plastik. Mulsa plastik merupakan salah satu cara yang dapat dilakukan untuk mengubah lingkungan tumbuh agar sesuai dengan kebutuhan tanaman. Mulsa dapat menaikkan suhu tanah pada musim kemarau sehingga cocok bagi kebutuhan tanaman (Rukmana, 2002). Hasil penelitian Sudjianto dan Krestiani (2009) pemulsaan menggunakan plastik hitam perak menghasilkan berat buah 
pertanaman, per petak dan kadar gula buah yang tertinggi. Penelitian ini bertujuan untuk mengetahui respon pertumbuhan dan hasil tanaman melon dengan pemberian POC kotoran sapi dan mulsa plastik.

\section{METODE PENELITIAN}

Bahan yang digunakan dalam penelitian adalah bijimelon varietas Action-434, kotoran sapi dan mulsa plastik hitam perak. Alat yang digunakan dalam penelitian adalah cangkul, meteran, polpen, buku catatan, timbangan, pisau, ember, gelas ukur dan kamera. Penelitian ini menggunakan metode Rancangan Acak Kelompok (RAK) dengan 6 perlakuan dan setiap perlakuan diulang sebanyak 4 kali, sehingga terdapat 24 unit percobaan. Adapun perlakuan yang diberikan sebagai berikut: P0 : Tanpa mulsa dan POC kotoran sapi (kontrol), P1 : mulsa dan POC kotoran sapi dengan konsentrasi 50 ml/tanaman, P2 : mulsa dan POC kotoran sapi dengan konsentrasi $100 \mathrm{ml} /$ tanaman, P3 : mulsa dan POC kotoran sapi dengan konsentrasi $150 \mathrm{ml} /$ tanaman, $\mathrm{P} 4$ : mulsa dan POC kotoran sapi dengan konsentrasi $200 \mathrm{ml} /$ tanaman, P5 : mulsa dan POC kotoran sapi dengan konsentrasi 250 $\mathrm{ml} /$ tanaman. Data hasil pengamatan dianalisis dengan menggunakan software SAS. Data pengamatan kemudian dianalisis secara statistik menggunakan sidik ragam (Analisis Sidik Ragam). Apabila hasil analisis varian menunjukkan adanya beda nyata antar perlakuan, analisis dilanjutkan dengan uji jarak ganda Duncan (DMRT).

Pembuatan POC dari kotoran sapidilakukan dengan cara : (a). Sediakan bahan-bahan dalam pembuatan POC kotoran sapi yaitu kotoran sapi sebanyak 4 $\mathrm{kg}$, air sebanyak 8 liter, EM4 dan gula merah 500 g; (b). Siapkan wadah yaitu ember yang ada tutupnya yang akan digunakan sebagai media pembuatan POC kotoran sapi kemudian masukkan semua bahan lalu diaduk sampai semua bahan tercampur rata; (c). Setelah tercampur merata kemudian ember ditutup. Larutan kemudian didiamkan dalam ember selama tiga minggu. Setiap tiga hari sekali dilakukan pengadukan dengan cara menguncang-guncangkan atau mengaduk lagi larutan; (d). Setelah masa fermentasi berakhir kemudian larutan disaring beberapa kali sehingga terpisah dari ampasnya.

Pengolahan lahan dilakukan dengan cara membersihkan gulma yang berada di lahan tempat penelitian dengan memangkas atau mencangkul gulma yang ada selanjutnya bersihkan area yang akan dijadikan sebagai lahan penelitian sampai tidak ada lagi terlihat rumput atau gulma. Setelah lahan dibersihkan, kemudian dibuat bedengan sebanyak 24 bedengan 
dengan ukuran masing-masing bedengan tinggi $25-30 \mathrm{~cm}$, lebar $60 \mathrm{~cm}$, dan panjang $60 \mathrm{~cm}$. Penanaman dilakukan dengan cara membuat lubang tanam sedalam $2-3 \mathrm{~cm}$ untuk bibit melon yang telah siap tanam. Setelah bibit melon tumbuh hingga 20 atau $30 \mathrm{~cm}$ buatkan penyanggah untuk menopang pertumbuhannya. Penyanggah yang digunakan dibuat dari bambu dengan tinggi mencapai $2 \mathrm{~m}$.

Pemasangan mulsa plastik hitam perak yang dilakukan sebelum penanaman tanaman melon. Pemasangan dilakukan memanjang pada bedengan. Mulsa plastik yang berwarna hitam menghadap ke bawah dan yang berwarna perak menghadap ke atas. Pemasangan mulsa plastik dilakukan saat matahari terik agar proses pemuaian optimal dan mulsa dapat menutup rapat pada bedengan. Aplikasi POC kotoran sapi dilakukan sebanyak 4 kali yaitu saat tanaman berumur 2, 4, 6, dan 8 minggu setelah tanam. Aplikasi dilakukan dengan cara menyiramkan POC pada sekitar tanaman dengan jarak 2-3 cm dari pangkal batang. Pengaplikasian dilakukan pada saat pagi hari. Parameter yang diamati meliputi komponen pertumbuhan yaitu panjang tanaman $(\mathrm{cm})$ dan jumlah daun (helai) serta komponen hasil yaitu jumlah buah, bobot buah $(\mathrm{kg})$, dan diameter buah $(\mathrm{cm})$.

\section{HASIL DAN PEMBAHASAN}

\section{Panjang Tanaman (cm) dan Jumlah Daun (helai)}

Tabel 1. Panjang Tanaman (cm) dan Jumlah Daun (helai) tanaman melon pada umur 14, 21, dan 28 (hari setelah tanam) pada pemberian POC kotoran sapi dan mulsa plastik.

\begin{tabular}{lcccccc}
\hline \multirow{2}{*}{ Perlakuan } & \multicolumn{3}{c}{ Panjang tanaman $(\mathrm{cm})$} & \multicolumn{3}{c}{ Jumlah daun (helai) } \\
\cline { 2 - 7 } & $14 \mathrm{hst}$ & $21 \mathrm{hst}$ & $28 \mathrm{hst}$ & $14 \mathrm{hst}$ & $21 \mathrm{hst}$ & $28 \mathrm{hst}$ \\
\hline P0 & $12.73 \mathrm{c}$ & $20.42 \mathrm{a}$ & $25.00 \mathrm{e}$ & $3.37 \mathrm{~d}$ & $5.37 \mathrm{c}$ & $8.12 \mathrm{D}$ \\
P1 & $14.77 \mathrm{bc}$ & $20.12 \mathrm{a}$ & $33.62 \mathrm{de}$ & $4.62 \mathrm{bcd}$ & $7.62 \mathrm{bc}$ & $10.50 \mathrm{Bcd}$ \\
P2 & $17.90 \mathrm{abc}$ & $22.47 \mathrm{a}$ & $38.52 \mathrm{~cd}$ & $4.37 \mathrm{~cd}$ & $6.62 \mathrm{bc}$ & $9.62 \mathrm{Cd}$ \\
P3 & $16.87 \mathrm{abc}$ & $22.22 \mathrm{a}$ & $44.47 \mathrm{bc}$ & $5.75 \mathrm{abc}$ & $8.25 \mathrm{abc}$ & $12.87 \mathrm{Abc}$ \\
P4 & $22.00 \mathrm{a}$ & $23.77 \mathrm{a}$ & $51.47 \mathrm{ab}$ & $6.12 \mathrm{ab}$ & $9.25 \mathrm{ab}$ & $14.12 \mathrm{Ab}$ \\
P5 & $20.12 \mathrm{ab}$ & $23.95 \mathrm{a}$ & $58.02 \mathrm{a}$ & $7.00 \mathrm{a}$ & $11.87 \mathrm{a}$ & $16.62 \mathrm{~A}$ \\
\hline Rerata & 17.40 & 22.16 & 41.85 & 5.20 & 8.16 & 11.97 \\
Cv & 23.23 & 15.82 & 14.05 & 18.29 & 28.18 & 22.24 \\
\hline
\end{tabular}

Keterangan : Nilai-nilai yang diikuti oleh huruf yang sama menunjukkan tidak berbeda nyata pada Uji Jarak Berganda Duncan (DMRT) pada taraf nyata 5\%.

\section{Jumlah Buah, Bobot Buah (kg), dan Diameter Buah (cm).}

Tabel 2. Rata-rata jumlah buah, bobot buah $(\mathrm{kg})$ dan diameter buah $(\mathrm{cm})$ tanaman melon

\begin{tabular}{lclclc}
\hline \multicolumn{1}{c}{ Perlakuan } & Jumlah buah & \multicolumn{2}{c}{ Bobot buah } & \multicolumn{2}{c}{ Diameter Buah } \\
\hline P0 & 1.12 & $\mathrm{~d}$ & 1.02 & $\mathrm{c}$ & $18.25 \mathrm{~A}$ \\
P1 & $2.50 \mathrm{~cd}$ & 1.37 & $\mathrm{~b}$ & $17.63 \mathrm{Ab}$ \\
P2 & 2.87 & $\mathrm{c}$ & 2.07 & $\mathrm{~b}$ & $18.25 \mathrm{~A}$ \\
P3 & $4.00 \mathrm{ab}$ & 2.10 & $\mathrm{a}$ & $17.63 \mathrm{Ab}$
\end{tabular}




\begin{tabular}{|c|c|c|c|}
\hline P4 & $3.62 \mathrm{ab}$ & $2.10 \quad \mathrm{a}$ & 17.63 \\
\hline P5 & 4.27 & 2.25 & 18.25 \\
\hline Rerata & 3.08 & 1.82 & 17.94 \\
\hline
\end{tabular}

Berdasarkan hasil penelitian (tabel 1). Dapat diketahui bahwa panjang tanaman melon dari umur 14 hst hingga 28 hst memiliki panjang tanaman maksimal diantara semua perlakuan yaitu pada perlakuan P5 dengan nilai rata-rata 58, 02 $\mathrm{cm}$. Sementara nilai yang paling terendah hingga tanaman berumur 28 hst yaitu pada tanaman kontrol (tanpa perlakuan) dengan rata-rata panjang tanaman sebesar 25.00. Hal ini menggambarkan bahwa dengan pemberian mulsa plastik dan POC kotoran sapi dengan dosis yang paling tinggi (Pemberian mulsa dan POC kotoran sapi dengan konsentrasi $250 \mathrm{ml} /$ tanaman) pada percobaan yang dilakukan masih lebih baik dari perlakuan yang lainnya. Diduga dikarenakan nutrisi yang terpenuhi bagi tanaman berkorelasi terjadinya fotosintesis dengan baik, sehingga pertumbuhan tanaman sangat dipengaruhi oleh ketersediaan unsur hara yang dapat diserap oleh tanaman. Unsur yang memiliki peran penting dalam hal pertumbuhan tanaman yaitu salah satunya nitrogen. Kandungan nitrogen dalam POC kotoran sapi cukup tinggi sehingga memungkinkan dapat memberikan tambahan kebutuhan unsur hara bagi tanaman. Pemberian nitrogen yang optimal atau dengan dosis yang sesuai dapat meningkatkan sintesis protein, pembentukan klorofil yang menyebabkan warna daun menjadi lebih hijau dan meningkatkan ratio pucuk akar. Oleh karena itu pemberian nitrogen yang optimal dapat meningkatkan laju pertumbuhan tanaman (Nur dan Thohari, 2005).

Hasil yang sama juga terlihat pada rata-rata jumlah daun tanaman melon menunjukkan hasil terbaik pada perlakuan P5 (pemberian mulsa dan POC kotoran sapi dengan konsentrasi $250 \mathrm{ml} /$ tanaman) saat tanaman berumur 28 hst dengan ratarata mencapai 16.62 dan nilai terendah pada perlakuan P0 (kontrol) yang hanya memberikan rata-rata jumlah daun mencapai 8.12. Pemberian mulsa plastik dan POC kotoran sapi memberikan pengaruh pada jumlah daun tanaman melon, penjelasan ini sejalan dengan pendapat Lingga (1991), bahwa kesuburan daun akan cepat berubah dan dapat menumbuhkan tunas baru karena penyerapan hara $\mathrm{N}$ sehingga dapat meningkatkan pembentukan dan pertumbuhan daun pada tanaman. 
Pemberian mulsa plastik dan POC kotoran sapi (tabel 2.) memperlihatkan jumlah buah dan bobot buah yang terbaik yaitu pada perlakuan P5 (pemberian mulsa dan POC kotoran sapi dengan konsentrasi $250 \mathrm{ml} /$ tanaman) dengan rata-rata jumlah buah mencapai 4.27 dan bobot buah 2.25 $\mathrm{kg}$ dan nilai terendah yaitu pada perlakuan P0 (kontrol) yang hanya memberikan hasil rata-rata jumlah buah mencapai 1.12 dan bobot buah $1.02 \mathrm{~kg}$. Pemberian mulsa plastik dan POC kotoran sapi dapat memenuhi kebutuhan tanaman untuk pembentukan buah. Tercukupinya unsur hara pada tanaman sangat penting untuk hasil produksi dari tanaman yang dibudidayakan. Fase generatif berkaitan penting dengan fase vegetatif, artinya baik tidaknya pada saat fase generatif tergantung pada saat fase vegetatif tanaman. Tercukupinya unsur hara tanaman, terutama nitrogen, fosfat dan kalium berasal dari POC kotoran sapi yang diberikan pada fase vegetatif berdampak pada saat pembuahan tanaman melon. Keterangan ini sejalan dengan Tarsum (2012) menyatakan tanaman yang mempunyai pertumbuhan vegetatif baik akan mempunyai pertumbuhan produksi baik asalkan adanya penjagaan pemupukan yang berimbang serta unsur-unsur nitrogen, fosfor dan kalium untuk penguatan jaringan. Disamping itu, Menurut Novizan (2002) salah satu fungsi
$\mathrm{K}$ adalah memperbaiki kualitas buah pada masa generatif dan $\mathrm{P}$ berfungsi dalam pembentukan buah.Pemberian $\mathrm{N}$ yang cukup, menjamin pertumbuhan yang baik, hasil panen yang lebih tinggi dan buah berkembang penuh, unsur banyak berpengaruh terhadap pembungaan dan perkembangannya, kekerasan buah, warna buah, kandungan vitamin dan mempercepat pematangan buah, penggunaan pupuk $\mathrm{K}$ meningkatkan kandungan gula, kandungan vitamin, kandungan asam total serta menambah jumlah buah yang dipanen (Sutrisna dan Yanto, 2014).

Hasil rata-rata pada diameter buah memperlihatkan hasil yang sama yang lebih tinggi diantara perlakuan yaitu pada P0, P2, dan P5 dengan nilai yang sama sebesar $18.25 \mathrm{~cm}$. sementara yang lebih rendah yaitu pada perlakuan $\mathrm{P} 1, \mathrm{P} 3$, dan P4 dengan nilai rata-rata $17.63 \mathrm{~cm}$. Hal ini diduga karena terjadi translokasi fotosintat dengan jumlah cenderung sama pada beberapa perlakuan untuk penambahan diameter buah. Adanya perlakuan pemupukan POC kotoran sapi memiliki kandungan hara makro yang dapat meningkatkan pertumbuhan tanaman. Terpenuhinya kebutuhan unsur hara makro inilah yang diduga menyebabkan adanya pengaruh perlakuan pemupukan terhadap pertambahan diameter batang tanaman. 


\section{KESIMPULAN DAN SARAN}

Berdasarkan penelitian yang telah dilakukan, maka didapatkan beberapa kesimpulan yaitu :

1. Pemanfaatan mulsa plastik dan POC kotoran sapi berpengaruh nyata pada tinggi tanaman, jumlah daun, jumlah buah, bobot buah, dan diameter buah.Hal ini diduga disebabkan oleh penggunaan mulsa plastik dan nutrisi pada POC kotoran sapi mampu meningkatkan pertumbuhan dan hasil tanaman melon.

2. Pemanfaatan mulsa plastik dan POC kotoran sapi yang memberikan hasil terbaik pada perlakuan P5 (pemberian mulsa dan POC kotoran sapi dengan konsentrasi $250 \mathrm{ml} /$ tanaman) untuk jumlah buah 1.12 dan bobot buah 1.02 $\mathrm{kg}$.

\section{DAFTAR PUSTAKA}

Badan Pusat Statistik. 2017. Hortikultura Produksi Tanaman Buah Melon (Ton). http://www.bps.go.id/site/pilihd ata (Diakses pada 08 mei 2019).

Irfan. 2013. Respon bawang merah (Allium ascalonicum L.) terhadap zat pengatur tumbuhdan unsur hara. UIN RIAU. https:// www. download. Portal garuda.org.(Diakses pada 08 mei 2019).

Lingga, P. 1991. Kotoran Ternak Penyubur Tanah. Jakarta: Penebar Swadaya. 1998.
Petunjuk Penggunaan Pupuk. Penebar Swadaya, Jakarta.

Mayun. 2007. Pengaruh Dosis Pupuk Organik Cair Kotoran Sapi terhadap Pertumbuhan dan Produksi Tanaman Sawi Hijau (Brassica sinensis L.) (Electronic persion). Agroforestri7 (1), 43-49.

Muku, M.O. 2002. Pengaruh Jarak Tanam dalam Barisan dan Macam Pupuk Organik terhadap Pertumbuhan dan Hasil Tanaman Bawang Merah (Alium ascalonicumL.) di Lahan Kering. Pasca Sarjana, Universitas Udayana, Denpasar. Tesis. Tidak Dipulikasikan

Novizan, 2002. Petunjuk Pemupukan Yang Efektif. Agromedia Pustaka. Jakarta.

Nur, S dan Thohari, 2005.Tanggap Dosis Nitrogen dan Pemberian Berbagai Macam Bentuk Bolus Terhadap Pertumbuhan dan Hasil Tanaman Bawang Merah (Allium ascalonicum L). Dinas Pertanian Kabupaten Brebes.

Prajnanta. 2004. Melon, Pemeliharaan Secara Intensif dan Kiat Sukses Beragribisnis. Penebar Swadaya, Jakarta.

Rukmana, R. 2002. Budidaya Melon Hibrida. Kanisius, Yogyakarta

Sudjianto, U., dan Krestiani, V. 2009. Studi pemulsaan dan dosis NPK pada hasil buah melon (Cucumis melo L.), Fakultas Pertanian Universitas Muria Kudus.Kudus.

Sutrisna, N.,S. Yanto. 2014. Uji Formula NPK pada pertanaman cabai rawit dataran tinggi Lembang, 
Fakultas Pertanian Universitas Cokroaminoto Palopo

Jawa Barat. Agros. 16(1): 172181

Tarsum. 2012. Macam pupuk kandang dan dosis pupuk $\mathrm{KCl}$ terhadap pertumbuhan dan produksi terung (Solanum melongena L.). Skripsi. Jurusan Agroteknologi. Fakultas Pertanian. Universitas Islam Darul Ulum. Lamongan 